\title{
“A OBRIGAÇÃO É O TÉDIO” EM O PASSADO E O PRESENTE
}

\author{
"THE OBLIGATION IS THE BOREDOM" IN O PASSADO E O PRESENTE
}

\author{
Edimara Lisboa \\ Universidade de São Paulo
}

\begin{abstract}
RESUMO: Este trabalho discutirá o processo de adaptação cinematográfica da peça $O$ Passado e o Presente, de Vicente Sanches, pelo cineasta Manoel de Oliveira. Por seu caráter de experimentação, o filme homônimo ainda não traz os procedimentos de transposição característicos das adaptações oliveirianas, sendo construído em torno da lógica clássica dessa categoria de adaptação, que procura escapar à designação pejorativa de "teatro filmado". No nível temático, entretanto, esse filme inaugura um leitmotiv do cinema oliveiriano: a impossibilidade de atingir em vida o amor absoluto. A primeira fala do filme, quarta da peça, poderia ser a epígrafe de seus quatro longasmetragens de ficção seguintes: "o casamento é a obrigação e a obrigação é o tédio". Gostaríamos de tomar esta passagem como fio condutor de análise dos procedimentos de adaptação empregados nesse filme. No cotejo peça/filme é possível identificar desvios da obrigação de fugir do "teatro filmado" que acabam por revelar técnicas muito próprias do cinema oliveiriano e que muitas vezes passam desapercebidas em $O$ Passado e 0 Presente. Ao discutir esses desvios e suas relações com seus outros filmes adaptados de peças, esperamos contribuir para os estudos da obra de Manoel de Oliveira, cujo diálogo com o teatro perpassa temas e técnicas.
\end{abstract}

PALAVRAS-CHAVE: Manoel de Oliveira; Teatro e cinema; Adaptação; Vicente Sanches

ABSTRACT: This paper will discuss the process of film adaptation from the play $O$ Passado e o Presente by Vicente Sanches, by filmmaker Manoel de Oliveira. Because it is experimental, the homonym movie still does not bring the transpositions characteristic of Oliveira's adaptations, being built around the classic logic of this category of adaptation, which seeks to escape of the pejorative designation "filmed theater". On a thematic level, however, this movie opens a leitmotiv of the Oliveira's filmography: the impossibility of achieving absolute love in life. The first line of the movie, the fourth line of the play, could be the epigraph of his four feature-length fiction films following: "the marriage is the obligation and the obligation is the boredom". We would like to take this passage as a thread analysis of procedures employed in this film adaptation. In compare play/movie is possible to identify deviations from the requirement to escape of the "filmed theater" that end up revealing techniques very own Oliveira's cinema and often go unnoticed in $O$ Passado e o Presente. When discussing these deviations and their relationships with their other movies adapted from plays, we hope to contribute to the study of the work of Manoel de Oliveira, whose dialogue with theater permeates themes and techniques.

KEYWORDS: Manoel de Oliveira; Theater and cinema; Adaptation; Vicente Sanches 


\section{Revista do SELL}

v. $4, n^{\circ} .2$

ISSN: $1983-3873$

O filme O Passado e o Presente (1972) de Manoel de Oliveira não é certamente um de seus filmes mais mobilizadores de estudos. Parece-me que isto se deve à posição fronteiriça em que ele muitas vezes é demarcado. Distingue-se dos documentários que assinalaram a primeira fase do cinema de Oliveira. Diferente de Aniki-Bobó (1942) não dialoga com uma escola artística de peso como o Neorrealismo Italiano. E ao contrário dos outros filmes da tetralogia dos amores frustrados, não é adaptação de um escritor português de grande prestígio. Baseado em obra homônima, uma das primeiras peças teatrais de Vicente Sanches, à época um jovem professor de filosofia do liceu (ensino médio), o enredo do filme gira em torno da curiosa história de uma mulher que, casada em segundas núpcias, vive em função do primeiro marido, já morto.

Manoel de Oliveira diz em entrevista que esse foi o primeiro texto para teatro que sentiu "necessidade de concretizar em cinema" (Oliveira, 1996, p. 33). Por seu caráter de experimentação, $O$ Passado e o Presente ainda não traz os procedimentos de transposição característicos das adaptações oliveirianas, sendo construído em torno da lógica clássica dessa categoria de adaptação, que procura sobrepor às indicações cênicas do texto escrito elementos próprios da linguagem cinematográfica, a fim de escapar à designação pejorativa de "teatro filmado". No nível temático, entretanto, 0 Passado e o Presente inaugura um leitmotiv do cinema oliveiriano: a impossibilidade de atingir em vida o amor absoluto. A primeira fala do filme, quarta da peça, bem poderia ser a epígrafe de seus quatro longas-metragens de ficção seguintes: "o casamento é a obrigação e a obrigação é o tédio. Do tédio vem discórdia e a discórdia é o inferno!".

Para Vanda, o amor no casamento só começa depois da morte dos maridos. A situação de suas duas amigas, Noêmia e Angélica, também revelam a fragilidade do casamento como instituição social oficializada. Para Noêmia só é possível prosseguir vivento com Fernando, seu ex-marido, enquanto ele continuar na situação legal de ex. Para Angélica, o casamento com Honório é um pilar que sustenta e estimula sua relação com Maurício, interrompida sempre que se torna uma situação regular. Em Benilde, ou a Virgem Mãe o casamento com seu primo Eduardo é a tábua de salvação uma e outra vez recusada por Benilde. Em Amor de Perdição o cerne da tragédia é a oposição dos pais ao casamento por amor entre Simão e Teresa e a insistência no casamento de conveniências entre Teresa e seu primo Baltasar. Já em Francisca, o enciumado Camilo consegue inviabilizar a consumação do casamento de Fanny e José Augusto, ainda que eles se amassem mutuamente. O casamento, nesses filmes, é fator de complicação e não elemento do desenlace eufórico, como nas comédias de costumes. 


\section{Revista do SELL}

v. $4, n^{\circ} .2$

ISSN: $1983-3873$

Mas essa ideia de que "o casamento é a obrigação e a obrigação é o tédio" também pode servir como fio condutor de análise dos procedimentos de adaptação empregados nesse filme e sobre os quais nos deteremos neste trabalho. No cotejo livro da peça / dvd do filme é possível identificar desvios da obrigação de fugir do "teatro filmado", tido por casamento infeliz e tedioso entre o teatro e o cinema, e esses desvios acabam por revelar técnicas muito próprias da estética oliveiriana, retomadas em suas outras adaptações de peças de teatro, e que muitas vezes passam desapercebidas ao espectador de O Passado e o Presente.

Em artigo sobre o papel da mulher na filmografia oliveiriana, João Bénard da Costa já defende a existência de elementos formais muito característicos do cinema de Oliveira que apareceriam discretamente em O Passado e o Presente, atentando para o seguinte:

[...] é sobretudo a partir de Benilde que Oliveira reflete seu famoso axioma sobre a inexistência do cinema ou o da exclusiva existência como meio audiovisual para fixar o teatro. [...] só a partir de Benilde se encontra algumas das figuras maiores do seu estilo. Mas, embora neste filme [ $O$ Passado e o Presente], a quase vertiginosa mobilidade da câmera, e a abordagem relativamente convencional do texto de Vicente Sanches (arejando a peça e fugindo freqüentemente à unidade de lugar) se afastem sensivelmente dos rumos futuros da obra de Oliveira, intervêm nele, e pela primeira vez intervêm, dominantemente, outras características maiores que, depois, recorrentemente, regressariam (Costa, 2005, p. 119).

Os elementos formais tipicamente oliveirianos que Bénard da Costa acentua são: Primeiro, a alternância de grandes sequências sem diálogos com sequências muito faladas. Neste filme, Oliveira entrelaça duas séries de episódios: completamente mudos (apresentados via imagem e música) e inteiramente falados (com o diálogo como a ação). Sendo silenciosas as cenas imaginadas por Oliveira, enquanto as cenas previstas pela peça são tagareladas, ambas montadas em ziguezague, em longos e contrastantes blocos. Esse procedimento reaparece, por exemplo, em Vou Para Casa, Viagem ao Princípio do Mundo e O Convento. Segundo, a teatralidade assumida pelos protagonistas fantasmagóricos, que se movem como espectros. O aspecto artificial das cenas é salientado pela mistura do elenco, composto por atores experientes, como Manuela de Freitas, que interpreta Noêmia; atores amadores, como João Bénard da Costa, sob o pseudônimo de Duarte de Almeida, interpretando Firmino; e mesmo não atores, como a própria Vanda, interpretada por Maria Reis, que inclusive disse em depoimento que só suporta ver-se nas cenas em que não fala (Cruz, 2009, p. 104). O elenco misto é um procedimento que Oliveira utiliza em quase todos os seus filmes. 


\section{Revista do SELL}

v. $4, n^{\circ} .2$

ISSN: $1983-3873$

A esses exemplos, gostaríamos de acrescentar outras importantes particularidades do processo de adaptação de peças de teatro em filmes empregado por Oliveira:

1‥ A insistência de reproduzir literalmente os diálogos originais. Em texto formidável sobre O Passado e o Presente, João César Monteiro reparava que: "a burguesia não se reconhece nem se identifica [...] num filme que, de artifício em artifício, a desfigura e artificiosamente a reinventa como expressão de um grotesco puramente teatral. Não só aquilo que os actores dizem é falso, como é falsa a maneira como o dizem" (Monteiro, 1974, p. 2) e acrescenta:

Meus bons senhores: para fazer passar (tornar audível) um texto que eu não ousaria ler em voz alta aos meus melhores inimigos (seria, aliás, redundante, até porque os meus melhores inimigos escrevem mal e filmam pior), não basta ser doido varrido. É preciso ser também absolutamente genial. [...] Será que os nossos radiofónicos ouvidos de portugueses já não distinguem, ao menos, que no filme de Oliveira se fala um português que nada tem a ver com o português que se fala nos restantes filmes nacionais? (Monteiro, 1974, p. 3).

Apesar de se preocupar, durante a preparação do roteiro, em transformar a obra de Vicente Sanches em uma história definitivamente cinematográfica, principalmente no que diz respeito à dinâmica de localização, Manoel de Oliveira praticamente não mexe nos diálogos. O tom enfaticamente declamado das conversas comezinhas daquele grupo de amigos burgueses somado à inexperiência de grande parte do elenco fogem ao primeiro preceito do cinema anti "teatro filmado": o esforço de fazer a realidade da peça se confundir com a própria vida. Característica que só Ihe será notada, definitivamente, a partir de Amor de Perdição, o excessivo respeito às palavras autorais do texto-fonte colabora para a complexidade de $O$ Passado e o Presente, que não apenas apresenta um tema ficcional atrativo ao grande público, mas oferece um modo de contar cinematográfico refinado e crítico. Os personagens de $O$ Passado e o Presente insistem na autenticidade de sua maneira de viver ainda que em transgressão aos valores de sua classe e, paradoxalmente, usam palavras muito pensadas, formulam suas reflexões cotidianas com certo esnobismo. Característica ainda mais expressiva na peça, principalmente na passagem em que os amigos de Vanda repreendem a criada por vir conta-Ihes sobre a briga que acontecia naquele momento entre Vanda e o marido, e que Ihe pareceu excessivamente violenta:

Tomar conselho conosco! Pôr-nos ao corrente da situação! (Semi à parte:) $\mathrm{Ai}$ isto é incrível, pura e simplesmente! Esta rapariga não regula da 


\section{Revista do SELL}

v. $4, n^{\circ} .2$

ISSN: $1983-3873$

cabeça! É de uma inconveniência... inclassificável! Inaudita! Nunca vista! Pois quando, sim, quando é que se viu uma criada vir à sala - comunicar às visitas que os donos da casa se encontram à bulha?! [... depois para ela] Julgamos que você, para ser uma criada decente numa casa de família, tem ainda muito o que aprender (Sanches, 1976, p. 177, 180).

$2^{\circ}$. A constante transgressão às indicações cênicas das rubricas. Manoel de Oliveira reproduz os diálogos literalmente, ainda que tenha optado por fazer alguns saltos e por alterar consideravelmente os acontecimentos do terceiro ato. Entretanto, não segue praticamente nenhuma orientação das rubricas. No início da história, Vanda reúne os amigos para irem juntos à cerimônia de transladação do corpo de seu primeiro marido, Ricardo, para o qual encomendou um suntuoso jazigo. Na peça, indica-se que enquanto Vanda vestia-se inteiramente de preto, os amigos apenas apresentavam um leve sinal de luto, de certa forma antecipando suas reservas quanto à atitude devocional de Vanda para com o falecido Ricardo diante do seu atual marido, Firmino. Oliveira opta, a esse respeito, por deixar os amigos trajarem-se inteiramente de luto, compactuando completamente com a anfitriã (Figura 1). Outro exemplo: Na cena em que Vanda e os amigos aguardam o diagnóstico do médico sobre o estado de Firmino, que ao fim tentou suicidar-se, uma rubrica indica que, após contar o conteúdo do bilhete suicida que ele deixou, perdoando-a "de tudo", Vanda sai irritada com o tom complacente do marido moribundo. No filme, nesse momento, além de Vanda, as amigas também saem de cena, reocupadas com seu estado, elas a seguem. Com isso, o diálogo seguinte, sobre a loucura de Vanda, transforma-se em uma conversa masculina, da qual Noêmia e Angélica não são mais ouvintes condescendentes (Figura 2).

Figura 1: Vestes de luto dos amigos

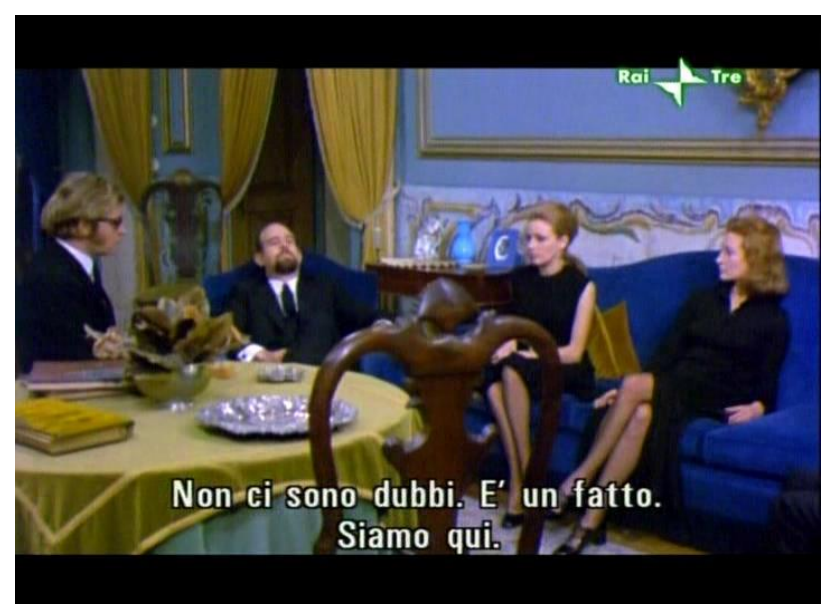




\section{Revista do SELL}

v. $4, n^{\circ} .2$

ISSN: $1983-3873$

Figura 2: Conversa masculina sobre Vanda

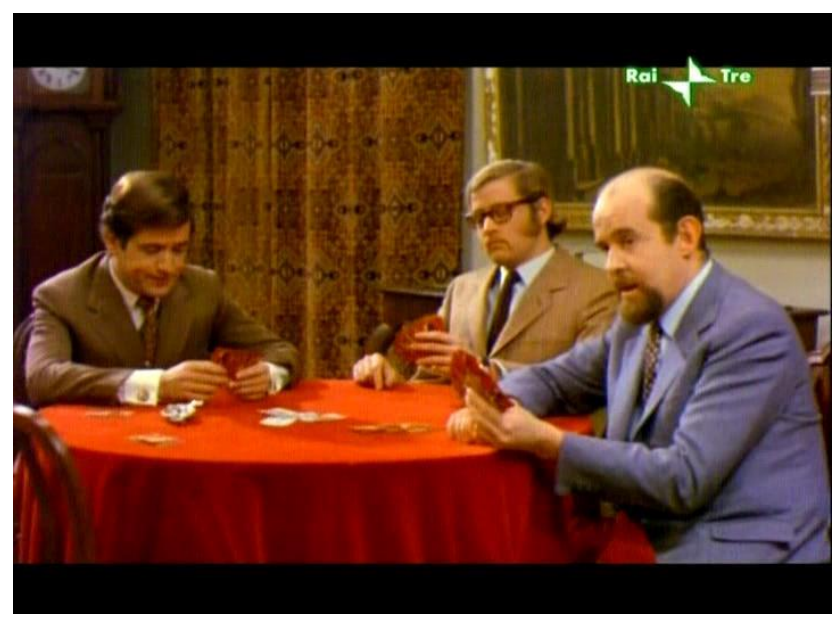

A transgressão às indicações cênicas das rubricas é um procedimento muito adotado por Manoel de Oliveira em suas adaptações de peças de teatro. Por exemplo, no filme O Quinto Império, Ontem como Hoje, adaptação da peça El-rei Sebastião de José Régio, o moço de câmera aumenta o tom de voz, quando deveria abaixar, D. Sebastião fala de costas para o público em direção às imagens santas na cortina, quando a rubrica indica que ele fala de frente para o público, ajoelhado e olhando para o alto. Em O Sapato de Cetim, da peça de Paul Claudel, alguns cenários foram propositalmente preparados à revelia das indicações cênicas da peça escrita. Em Benilde, ou Virgem-Mãe, da peça de Régio, a atitude dos personagens é quase sempre oposta à sugestão da rubrica, falam brandamente quando deveriam gritar, aceleram o ritmo da frase quando deveriam dar uma pausa. Em O Meu Caso, novamente uma peça de Régio, a transgressão chega à minúcia de colocar o biombo à direita, quando foi indicado que ele ficaria à esquerda.

3‥ A personificação do espaço cênico. A casa, um belíssimo palacete, com suas várias salas e quartos, amplia o espaço restrito da sala de estar na qual se passa todo drama de Vicente Sanches. E, ao fazer isso, revela-se ao olho indiscreto da câmera em suas mais singelas particularidades. A boneca de gesso junto a um espelho, os muitos espelhos, a louça, os livros, a mesa de bilhar, o piano, as cortinas, os tapetes, os castiçais são mostrados com uma ênfase distinta, através dos ângulos mais variados e ao longo de vários travellings que conferem a casa não apenas a caracterização do modo de vida de uma classe, como também uma memória familiar. Todo filme se constrói em torno da casa. A casa de $O$ Passado e o Presente traz uma aura histórica, através dos móveis e de seus elementos decorativos, que, acumulados ao longo de muitos anos, atravessam 


\section{Revista do SELL}

v. $4, n^{\circ} .2$

ISSN: $1983-3873$

gerações. Ricardo, o primeiro marido de Vanda, que retorna a vida conjugal após revelar que quem realmente morreu foi seu irmão gêmeo, Daniel, por duas vezes observa com atenção a sacada de onde Firmino jogou-se. Firmino estava morto, mas a recordação de sua existência sobrevivia através daquela sacada. Como sobrevivia no redescoberto amor de Vanda por ele.

É digno de nota o fato de a casa de O Passado e o Presente ser a casa do autor da peça, a casa em que ele vive ainda hoje, onde concebeu e escreveu o texto. Manoel de Oliveira conta em entrevista que a casa da família de Vicente Sanches em Castelo Branco não foi a sua primeira escolha para o filme e que o roteiro fora inclusive escrito a partir do plano de outra casa, que ao fim não recebeu autorização de filmar, e admitiu que "outra casa teria dado outro filme" (Oliveira, 1999, p. 51). Apesar de não planejadas, as imagens da casa real do autor adaptado acabam por testemunhar a época e o lugar de onde fala, a cosmovisão subjacente ao texto. A casa de $O$ Passado e o Presente, como um verdadeiro personagem, tem o seu caráter e a sua psicologia. Revela uma certa pompa e sobretudo uma inquietação, acerca da morte e em torno do amor. Nos filmes de Oliveira, com frequência, intervém uma casa, como na Divina Comédia e em Vale Abraão, em que as paredes, a mobília e o serpentear dos corredores transparecem o que há de social (salas, escritórios) e íntimo (quartos, banheiros) no cotidiano de uma família.

4․ O motivo da carta. As cartas materializam o desejo de Vanda, apenas latente na peça, de voltar a falar com seus maridos mortos. Em seu primeiro plano no filme, ela escreve e reescreve um bilhete para acompanhar as flores que encomendou para o jazigo de Ricardo (Figura 3). Depois, será na mesma escrivaninha e valendo-se da mesma esferográfica que Firmino escreverá seu bilhete suicida (Figura 4), despedaçado por Vanda enquanto ele agonizava sobre a cama e, mais tarde, após a retomada do casamento dela com Ricardo, relembrado uma e outra vez, em seus sonhos. A carta, em O Passado e o Presente, é o único modo de se comunicar com quem já não está vivo. $\mathrm{Na}$ filmografia oliveiriana as cartas constantemente aparecem como elemento estruturante e particularizador de determinadas soluções estéticas. Com aparência de elemento acessório na composição narrativa do filme, interferem grandemente no desenrolar dos fatos, como em Francisca, em que as cartas de Camilo são o veículo da tragédia, ou adensam a complexidade da obra, como em $A$ Carta, em que a carta enviada de África por $\mathrm{M}^{\mathrm{me}}$ de Clèves questiona a inexistência de comportamentos absolutamente estoicos como o dela, quer no presente quer no passado, através do depoimento do trabalho humanitário realizado por jovens freiras junto a refugiados de guerra. Em O Dia do 


\section{Revista do SELL}

v. $4, n^{\circ} .2$

ISSN: $1983-3873$

Desespero e em Palavra e Utopia as cartas ajudam a transportar para o interior do texto fílmico o texto literário e autoral do biografado, dando algum tempo a sós com o espectador para uma voz que geralmente não é ouvida com atenção no cinema, sufocada pelo discurso intermitentemente interpretativo dos narradores-biógrafos e apressada pela dinamicidade do encadeamento veloz dos fotogramas.

Figura 3: Vanda escreve bilhete

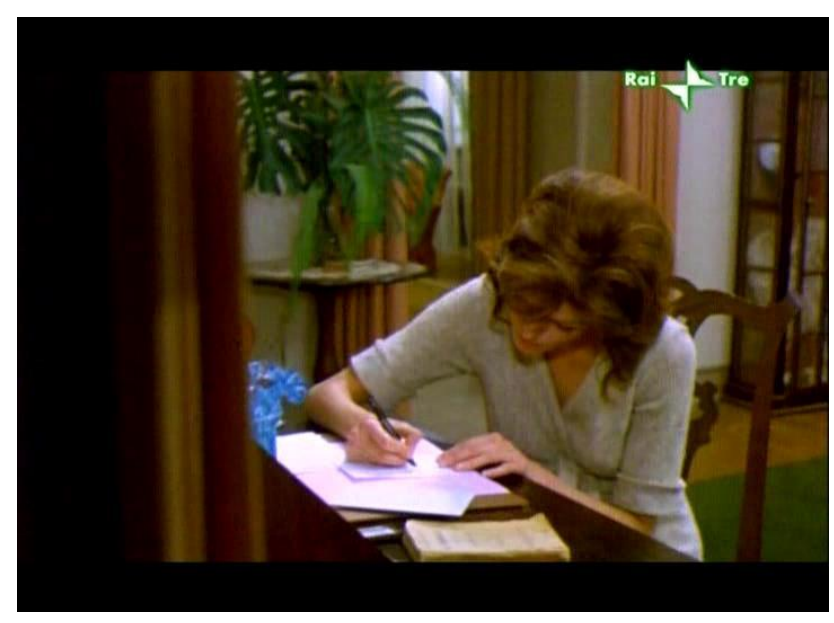

Figura 4: Firmino escreve bilhete

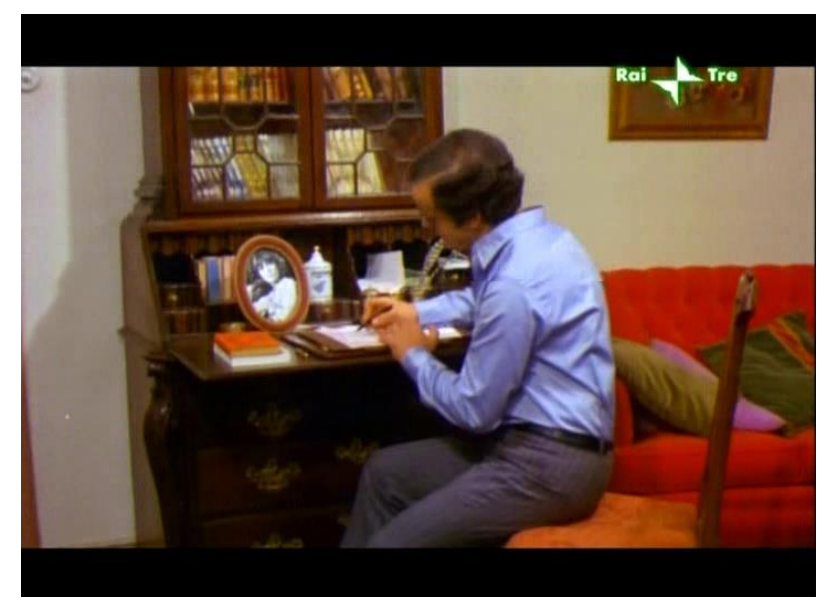

Gostaríamos, ainda, de discutir o uso dos procedimentos tradicionais da adaptação de peça em filme, justificadores da classificação de $O$ Passado e o Presente como caso anômalo na filmografia oliveiriana: 


\section{Revista do SELL \\ v. $4, n^{\circ} .2$ \\ ISSN: $1983-3873$}

1‥ A quebra da unidade de lugar. Toda a peça de Vicente Sanches se passa na sala de visitas da casa de Vanda. No filme, os personagens perambulam ao longo dos muitos ambientes do palacete de Vanda. Além disso, outras locações são acrescentadas, como a funerária, a floricultura, o cemitério, o escritório do advogado, a casa de Noêmia, o tribunal e a igreja.

$2^{\circ}$. A diluição da marcação temporal muito precisa. Cada ato da peça se passa em momento previamente determinado. O primeiro ato no dia da transladação do corpo de Ricardo. O segundo ato, meio ano depois, no dia da morte de Firmino. O terceiro ato, dois anos depois, durante uma visita corriqueira dos amigos de Vanda. No filme, cabe ao espectador se atentar à passagem do tempo e perceber que decorreu um ano (conforme o bilhete suicida) entre a transladação do corpo de Ricardo e a morte de Firmino e que passou algum tempo entre a revelação de Daniel e a legalização de seu retorno à vida de Ricardo. Porém, ainda que não seja determinado temporalmente o terceiro encontro dos amigos, ele é mais explicitamente justificado. Reuniram-se para irem juntos assistir a uma cerimônia de casamento. Há, ainda, episódios que ocorreram em dias diferentes ao dos três encontros: o passeio pelo jardim de Vanda e Ricardo, a visita dele ao advogado (Curiosamente chamado Cândido Pinto - nomes do meio de Manoel de Oliveira), a conversa ao telefone dela com Noêmia, entre outros.

3‥ A ampliação do elenco. Aumenta-se a carga expressiva dos empregados e trabalhadores que figuram ao redor de Vanda, a fim de salientar o caráter extremamente estratificado da sociedade burguesa. Os empregados do palacete de Vanda são observadores silenciosos em oposição a seus patrões muito faladores, assim como os plebeus de Os Canibais apenas falam enquanto a aristocracia comunica-se cantando. Mas também são observados pelos maridos de Vanda, que invejam a descomplicação de suas relações amorosas.

4ํ․ Transformação de sumários em novas cenas. Algumas deixas da peça são aproveitadas para adensar a narrativa. Vanda retira-se devido a uma dor de cabeça dando ensejo para que os amigos comentem seu caso. No filme, a câmera invade o quarto de Vanda para mostrar como ela repudia Firmino. Ao contar a história da troca de lugares entre os gêmeos, Daniel e Ricardo, um flashback mostra o momento do acidente, autentificando a história contada pelo falso Daniel. A sessão judicial que devolve a Ricardo seu nome e estado civil originais é mostrada. 


\section{Revista do SELL}

v. $4, n^{\circ} .2$

ISSN: $1983-3873$

5․ O acréscimo de motivos visuais reveladores do tema da história. Esculturas são objetos recorrentemente filmados por Manoel de Oliveira, aparecendo em praticamente todos os seus filmes. Em O Passado e o Presente aparece a imagem de ampulhetas com asas de morcego esculpidas nos muros do cemitério (Figura 5). Esta imagem, enquanto recurso poético, ilustra e adensa a ideia da fugacidade da vida, presente na obra de Vicente Sanches, como comenta o estado de espírito da protagonista. O tempo voa, mas Vanda, como um vampiro, agarra-se à lembrança necrófila do marido que não existe mais para enganar o tempo e continuar vivendo.

Figura 5: Ampulheta com asas de morcego

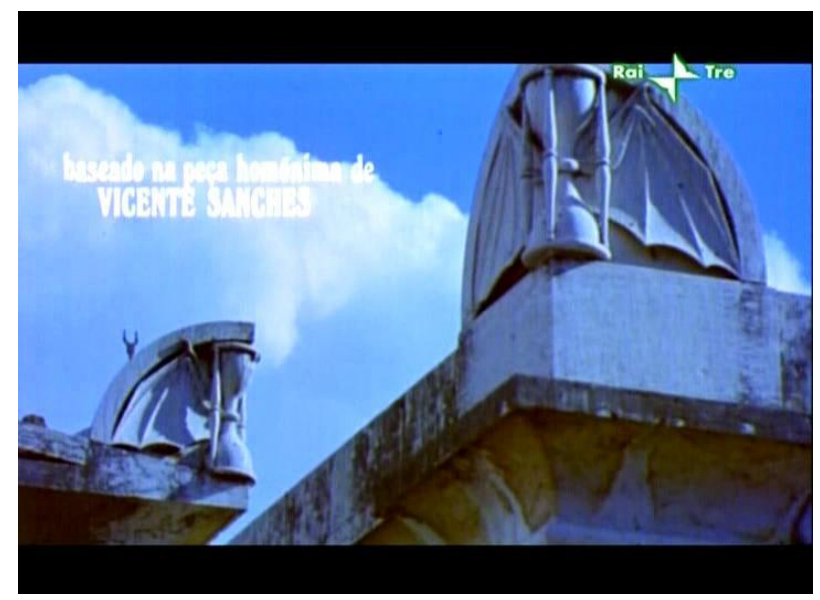

6․ O acréscimo de um tema musical, como trilha sonora cinematográfica. A opção pela inconfundível "Marcha nupcial" de Felix Mendelssohn não seria particularmente significativa se o filme não trouxesse também outra passagem (opus 62) da Música Incidental composta por ele para uma versão alemã da peça Sonhos de uma noite de verão de William Shakespeare. A peça de Shakespeare é uma história sobre o casamento, lembra-nos que, ao longo da história, o casamento raramente é uma questão de amor. A peripécia dos casais trocados, central na peça, é devida a uma flor vermelha mágica que, uma vez esfregada sobre os olhos adormecidos, fazem a pessoa apaixonarse pelo primeiro ser vivo em que por os olhos ao despertar. Numa relação intertextual complexa, que recupera a peça de Shakespeare através da música que a evoca, Manoel de Oliveira retoma o tema das flores vermelhas. No filme elas assumem uma dupla função, são flores para os vivos, na medida em que enfeitam a casa e lhe dar ares de habitação (Figura 6), e são flores para os mortos, oferecidas aos maridos mortos, em 


\section{Revista do SELL \\ v. $4, n^{\circ} .2$ \\ ISSN: $1983-3873$}

buquês para Ricardo (Figura 7) e, depois, plantadas pessoalmente por ela no canteiro em que Firmino caiu ao jogar-se da sacada (Figura 8). Maurício, a certa altura, chega a dizer: "O amor! [...] Irmão da morte! [...] Nunca se percebeu - dessa íntima e fraterna relação? [...] os poetas quase nunca se referem ao amor que não se refiram à morte. E vice-versa" (Sanches, 1976, p. 120). Expressão de amor e morte, flores de casamentos e flores de velórios, que não estão presentes no texto-fonte, ilustram as paridades entre essas duas questões centrais da peça.

Figura 6: Flores vermelhas para o túmulo de Ricardo

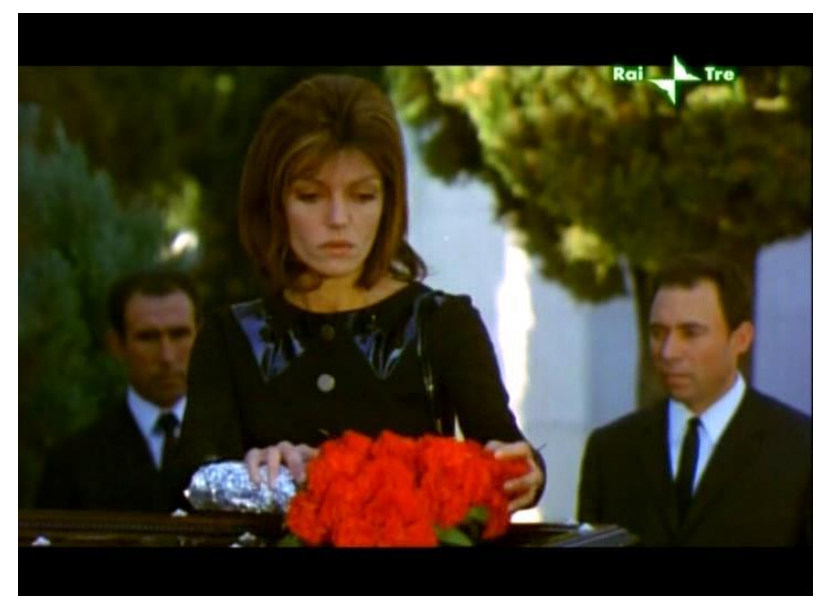

Figura 7: Flores vermelhas enfeitando a casa

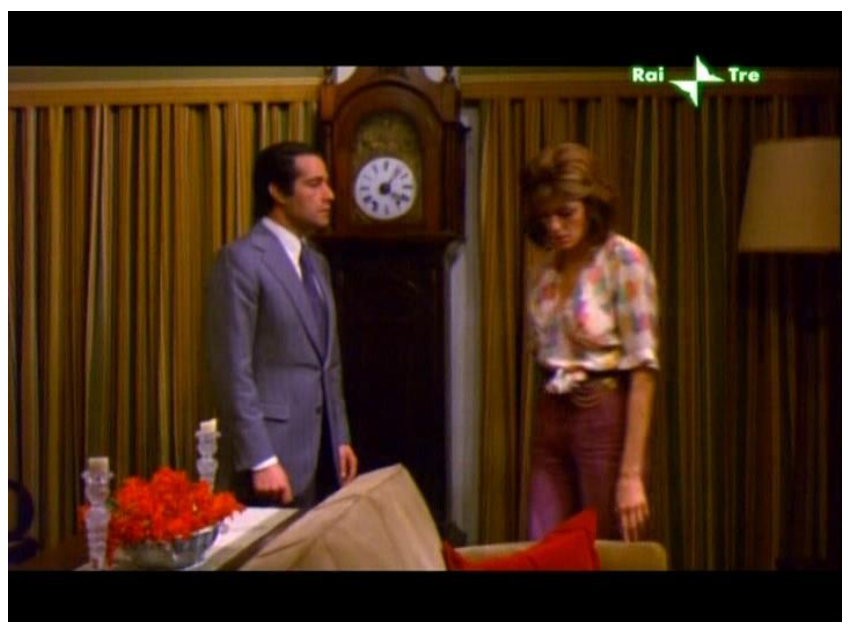




\section{Revista do SELL}

v. $4, n^{\circ} .2$

ISSN: $1983-3873$

Figura 8: Flores vermelhas para o falecido Firmino

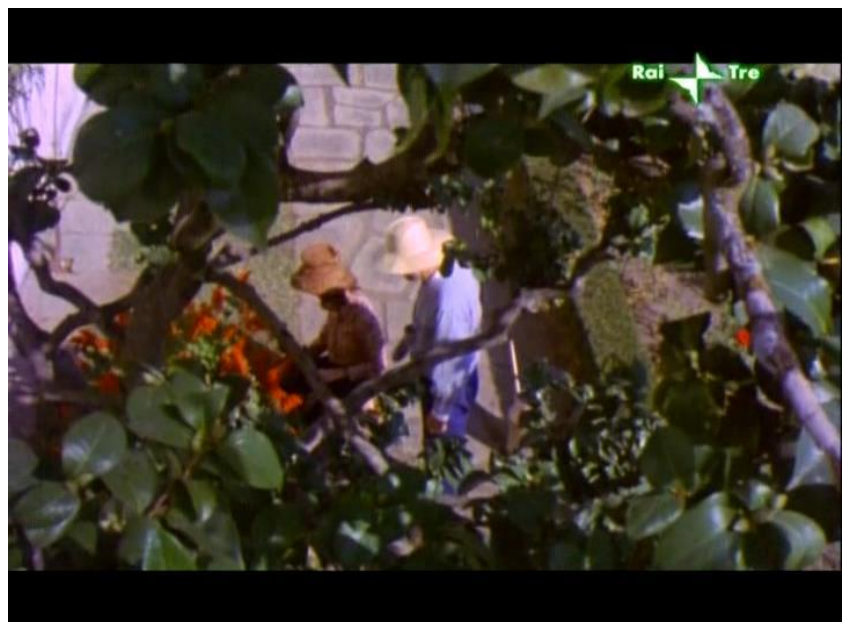

Deste modo, mesmo os elementos favorecedores de uma adaptação de teatro para cinema realizada segundo a gramática do gênero, não chegam a contradizer o estilo de Manoel de Oliveira. Ao aparentemente fugir do "teatro filmado", Oliveira não realiza o principal motivo desse procedimento, não transforma a representação teatral em simulação naturalista da própria vida. Embora atores e câmera se movimentem bastante entre variadas locações, a maioria dos enquadramentos de $O$ Passado e o Presente alude à reflexão estética da pintura e da fotografia artística, durante a lua de mel de Vanda e o ressuscitado Ricardo, por exemplo, a câmera simula um quadro de Claude Monet (Le bassin aux nympheas, 1919, óleo sobre tela, 100,4 x $201 \mathrm{~cm}$ ) (Figura 9). enquadramento/obra de arte afasta o espectador da cena, atrapalha a ilusão de realidade. A diluição do tempo não dá à história uma duração ampliada, mais próxima do romance e do cinema que do teatro, mas provocam uma atmosfera fabular muito distinta da vida real. A separação de classe não busca a identificação da alto-burguesia com o filme, mas provoca o espectador a questionar essa estratificação social. Numa história em que o ponto de vista está colado a protagonistas burgueses, os trabalhadores não poderiam ser mais que acessórios do décor. A visualização de episódios apenas sugeridos pela peça não apenas a ilustram, como também buscam lançar uma possível interpretação sobre ela. O comportamento do Firmino literário propõe um personagem masculino completamente sujeitado à mulher, que a eleva a um estado místico, por isso o Firmino fílmico espreita uma Vanda arrebatadora que só ele enxerga, sem ser capaz de tocá-la ou 


\section{Revista do SELL}

v. $4, n^{\circ} .2$

ISSN: $1983-3873$

feri-la (Figura 10). Prefere, por isso, matar-se a si do que a ela. O flashback da troca entre Ricardo e Daniel, ao invés de tornar o caso mais crível, aprofunda as dúvidas do espectador sobre sua realidade. Questionada mais abertamente na peça, em que a impressão digital se torna prova irrefutável. A trilha sonora não é apenas um acompanhamento musical, mas um complexo intertexto. A alteração de final não apenas areja espacialmente a história, como recoloca o problema do casamento em primeiro plano. No casamento de Raquel, nova personagem, o padre menciona o primeiro casamento, Eva foi criada especialmente para fazer companhia a Adão. O que ele não relembra é que ela acabou por ser o veículo da sua perdição. Já em $O$ Passado e o Presente, e mesmo antes, em Aniki-Bóbó, os homens oliveirianos estão sempre sujeitos às mulheres, são personagens previsíveis e artificiais frente a mulheres instigantes e imprevisíveis.

Figura 9: Vanda e Ricardo retomam o casamento

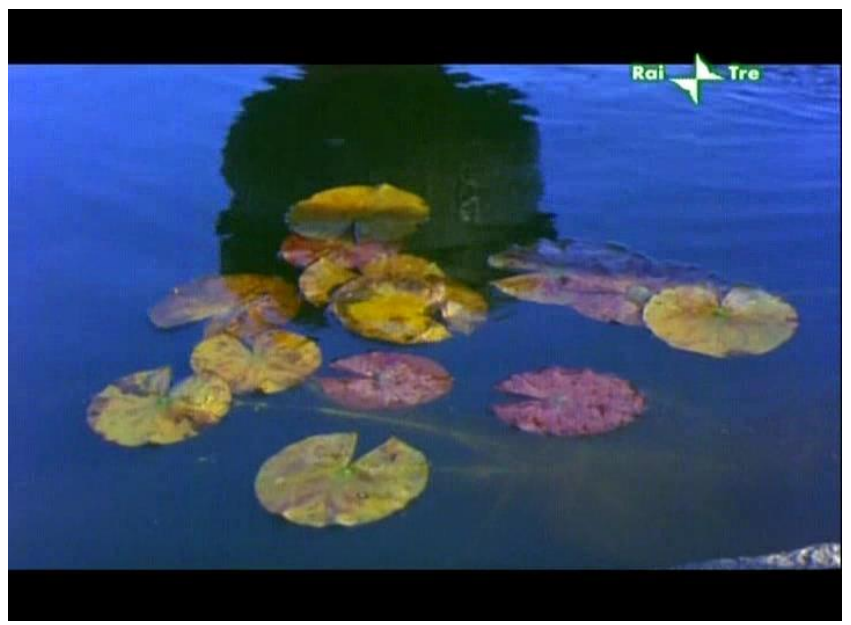

Figura 10: Firmino espreita Vanda

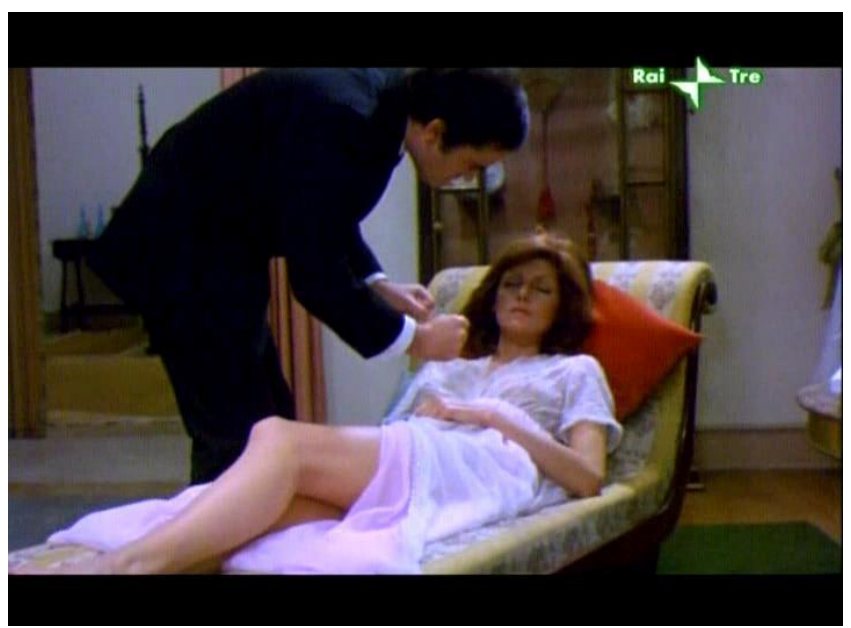




\section{Revista do SELL}

v. $4, n^{\circ} .2$

ISSN: $1983-3873$

Esses desvios em $O$ Passado e o Presente, e suas relações com outros filmes oliveirianos, são elementos fecundos para exploração do diálogo de Manoel de Oliveira com o teatro, que ao perpassar temas e técnicas, passando pelo seu famoso axioma de que "o cinema não existe, o que existe é o teatro", ${ }^{1}$ marca seu firme e autoral posicionamento estético.

\section{Referências bibliográficas}

COSTA, João Bécard da. Pedra de toque: o dito "eterno feminino" na obra de Manoel de Oliveira. MACHADO, Álvaro (Org.). Manoel de Oliveira. São Paulo: Cosac Naify, 2005, p. 116-164.

CRUZ, Jorge. Da literatura ao filme: acerca do processo de adaptação em Manoel de Oliveira. In: CRUZ, Jorge et al. Aspectos do cinema português. Rio de Janeiro: UFRJ, SR3, LCV, 2009, p. 101-125.

OLIVEIRA, Manoel de. Em Entrevista Panorâmica. In: MATOS-CRUZ, José de. Manoel de Oliveira e a montra das tentações. Lisboa: Dom Quixote, 1996.

OLIVEIRA, Manoel de. Em entrevista. In: BAECQUE, Antoine de; PARSI, Jacques. Conversas com Manoel de Oliveira. Porto: Campo das Letras, 1999.

SANCHES, Vicente. O Passado e o Presente. Comédia em três actos. 3. ed. rer. Castelo Branco: Gráfica São José, 1976.

\footnotetext{
1 "Será um atrevimento mas, para mim, o cinema em si não existe. O que há, é uma vontade de recriar a vida - ora, isso está no teatro. [...] O teatro é uma síntese de todas as artes, e assim também o cinema, com a capacidade suplementar da fixação" (Oliveira, 1996, p. 28).
} 